The Agriculturists 16(2): 65-74 (2018) ISSN 2304-7321 (Online), ISSN 1729-5211 (Print)

A Scientific Journal of Krishi Foundation

Indexed Journal

DOI: http://dx.doi.org/ 10.3329/agric.v16i02.40344

Impact Factor: 0.568 (GIF, 2015)

\title{
Yield Performance and Blast Susceptibility of Some Wheat (Triticum aestivum) Varieties in Jashore
}

\author{
R Islam ${ }^{*}$, Abdullah al Mamun ${ }^{2}$, M Jahangir Alam ${ }^{1}$, M B Anwar ${ }^{1}$ and M A Hakim ${ }^{3}$ \\ ${ }^{1}$ Regional Agricultural Research Station, Bangladesh Agricultural Research Institute, Jashore, \\ Bangladesh; ${ }^{2}$ Department of Agricultural Extension, Tala, Sathkhira, Bangladesh; ${ }^{3}$ Wheat Research \\ Centre, Bangladesh Agricultural Research Institute, Nashipur, Dinajpur, Bangladesh \\ *Corresponding author and Email: rabiwrcjess@yahoo.com
}

Received: 15 November 2018

Accepted: 25 December 2018

\begin{abstract}
A trial was conducted during 2015-16 to 2017-18 at the Regional Agricultural Research Station (RARS) of Bangladesh Agricultural Research Institute (BARI), Jashore to select some tolerant varieties against wheat blast. Fourteen varieties including eight old varieties (Sonalika, Kanchan, Sourav, Gourab, Shatabdi, Sufi, Bijoy, Prodip) and six newly released varieties (BARI Gom 25, BARI Gom 26, BARI Gom 27, BARI Gom 28, BARI Gom 29 and BARI Gom 30) were evaluated. The experiments were non-replicated and were planted in two sowing dates, at optimum (mid November) and late (mid December) conditions. Three irrigations were applied, at crown root initiation (CRI), heading and grain filling stages. Plants of border rows were inoculated by Magnaporthe oryzae triticum (MoT) spores $\left(10^{4}\right.$ conidia $\left.\mathrm{ml}^{-1}\right)$ for infection once per week from three weeks after sowing until primary infection was observed. The significantly higher grain yield was observed in 2016-17 $\left(3505 \mathrm{~kg} \mathrm{ha}^{-1}\right)$ which was similar to 2017-18 (3448 $\left.\mathrm{kg} \mathrm{ha}^{-1}\right)$ and the lowest was in 2015-16 (1680 kg $\mathrm{ha}^{-1}$ ). The higher grain yield was obtained due to the higher grains spike ${ }^{-1}$ (45 no.) and 1000 grain weight $(36.6 \mathrm{~g})$ and lower blast disease incidence (\% blast index $18.1 \%)$. In all three years, there was heavy infection of wheat blast in late sowing condition (\% blast index 40.7) compared to the optimum sowing condition (\% blast index 1.4), resulting in very poor crop yield (1696 kg ha $\mathrm{kg}^{-1}$ ). Among the varieties, the variety Gourab produced the highest yield $\left(3395 \mathrm{~kg} \mathrm{ha}^{-1}\right)$ which was similar to the newly released variety BARI Gom 28 (3196 kg ha ${ }^{-1}$ ) and BARI Gom 30 (3134 kg ha ${ }^{-1}$ ). In case of blast disease severity, old varieties were less infested with some exception in Sonalika and Kanchan. On the other hand, BARI Gom 25 and BARI Gom 26 were more susceptible (\% blast index 35.3-36.5) to wheat blast compared to BARI Gom 28 and BARI Gom 30 (\% blast index 20.2-22.5).
\end{abstract}

Keywords: Wheat blast, Variety, Magnaporthe oryzae, Temperature, Tolerance.

\section{Introduction}

Wheat (Triticum aestivum) is the second most important grain crop in Bangladesh after rice. Several biotic and abiotic stresses are the major constraints for the widespread cultivation of wheat. Among the diseases, leaf rust, leaf blight, head blight etc. are usually prevalent in this environment. However, wheat blast (or brusone), a new devastating wheat disease caused by Magnaporthe oryzae B.C. Couch (synonym Pyricularia oryzae Cavara) pathotype Triticum 
(MoT) emerged for the first time in 2016 in several southwestern and southern districts of Bangladesh. The disease was widespread accounting for approximately $15 \%$ of Bangladesh's total wheat area, which underscored a concern about the potential spread of wheat blast to other wheat producing areas in Bangladesh, South Asia and beyond. Wheat blast is new to Asia, known to cause significant crop losses in some South American countries with warm and humid condition. Comparative genome analyses revealed that the fungal isolates appeared in Bangladesh was clonal and closely related to highly aggressive MoT isolates from South America (Farman et al., 2017; Islam et al., 2016; Malaker et al., 2016). The disease was first observed in the state of Paraná, Brazil, in 1985 (Igarashi et al., 1986). Later on it spreads to Bolivia, Argentina and Paraguay (Duveiller et al., 2016). Due to lack of resistant cultivar and in effectiveness of fungicides at higher disease pressure, wheat blast is widely distributed across the wheat growing areas in Brazil, causing yield losses from 40-100\% (Silva et al., 2009; Maciel 2013; Castroagudin et al., 2016). In South America, more specifically Brazil, have some regions where the farmers don't go to grow wheat because of the disease (Callaway, 2016). The disease was also spotted in Kentucky, USA in 2011, however, vigorous surveillance helped to stop its spread over the country (Callaway, 2016).

Wheat blast is mainly a disease of spike, however, can occur on all aerial plant parts. Severity of the disease greatly depends upon weather conditions, cultivars, and plant organs infected (Goulart et al., 2007; Urashima et al., 2009). Although exact weather conditions required for a field epidemic are not clear, most severe blast outbreaks have coincided with wet years; warm temperatures and high humidity (Urashima et al., 2009). Lack of a complete understanding of ecological and epidemiological factors that drive wheat blast epidemics makes disease management a challenging task. It is important to determine the relative importance of potential primary sources of inoculums such as infected seeds (Urashima et al., 1999). However, seed infection may play a limited role in epidemiology but being seed-borne, wheat blast can spread easily via commercial grain shipments or farmer-to-farmer seed exchanges. The disease can be managed by the use of fungicides, resistant cultivars, agronomic practices and biotechnological methods (Ribot et al., 2008). Wheat blast fungus has physiologically and genetically complex character, with a range of aggressiveness and pathotypes. Most of the wheat cultivars are susceptible to wheat blast in Bangladesh (Malaker et al., 2016). Tolerant cultivars should have to identify in specific areas, but still yet to develop variety with durable resistance.

Therefore, a trial was implemented to find out blast resistant wheat varieties among the old and newly released varieties in Bangladesh.

\section{Materials and Methods}

\subsection{Soil and environment of site}

The experiment was conducted at the experimental farm of the Regional Agricultural Research Station of Bangladesh Agricultural Research Institute at Jashore $\left(23^{\circ} 11^{\prime} \mathrm{N}, 89^{\circ} 14^{\prime} \mathrm{E}\right.$ and $16 \mathrm{~m}$ ASL) during 2015-2018, in rabi seasons. The climate was subtropical monsoon with average annual rainfall of $1590 \mathrm{~mm}, 90 \%$ of which falls from June to October (Alam et al., 2017). Monthly mean rainfall was lower in November to March (about $20 \mathrm{~mm}$ rainfall occurred both in the later two years (2016-17 and 2017-18), whereas it was higher (57 $\mathrm{mm})$ in the first year (2015-16), especially more rainfall (42 $\mathrm{mm}$ ) in the maturity stage (Fig. 1). Monthly mean maximum temperature ranges from $24^{\circ} \mathrm{C}$ in December (2015-16) to $32^{\circ} \mathrm{C}$ in March of 2016-17 (Fig. 1). The soil was a calcareous brown clay loam of the High Ganges River Floodplain (BARC, 2012). Bulk density was 1.4$1.5 \mathrm{~g} \mathrm{~cm}^{-3}$ throughout the profile, apart from a slightly denser layer at $20-25 \mathrm{~cm}$. The topsoil $(0-$ $15 \mathrm{~cm})$ was slightly alkaline $(\mathrm{pH} 7.7)$ and had low soil organic C (1\%) content (Alam et al., 2017; 2018). 


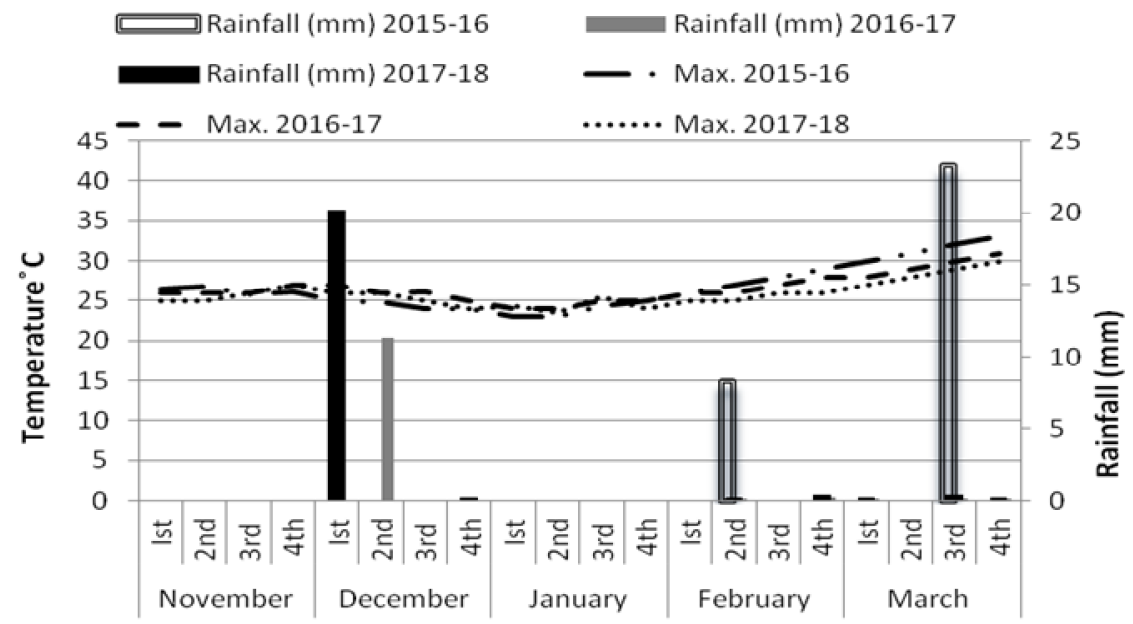

Fig. 1. Weekly average temperature and rainfall during Nov. to Aprl 2015 to 2018 at RARS wheat research field Jashore

\subsection{Experimental design}

The experiment was carried out with nonreplications in field conditions. Eight old varieties (Sonalika, Kanchan, Sourav, Gourab, Shatabdi, Sufi, Bijoy and Prodip) and six newly released varieties (BARI Gom 25, BARI Gom 26, BARI Gom 27, BARI Gom 28, BARI Gom 29 and BARI Gom 30) were used in the on station trial.

\subsection{Crop management}

A pre-sowing irrigation $(50 \mathrm{~mm})$ was applied about a week before sowing seeds. The experiments were earmarked for optimum (15-30 November) and late seeding (20-30 December), at $120 \mathrm{~kg}$ seed ha ${ }^{-1}$, with a sowing depth of 3-5 $\mathrm{cm}$ and row spacing of $20 \mathrm{~cm}$. The wheat seeds were treated with Provax-200@3 $\mathrm{g} \mathrm{kg}^{-1}$ seed and sown by hand seeding by maintaining equal row spacing. Total fertilizer application was $100 \mathrm{~kg}$ $\mathrm{N} \mathrm{ha}^{-1}$ as urea, $30 \mathrm{~kg} \mathrm{P} \mathrm{ha}^{-1}$ as triple superphosphate, $50 \mathrm{~kg} \mathrm{~K} \mathrm{ha}{ }^{-1}$ as muriate of potash, $20 \mathrm{~kg} \mathrm{~S} h a^{-1}$ as gypsum, $5 \mathrm{~kg} \mathrm{Zn} \mathrm{ha}^{-1}$ as zinc sulphate and $1 \mathrm{~kg} \mathrm{~B} \mathrm{ha}^{-1}$ as boric acid. Two thirds of the $\mathrm{N}$ and all the $\mathrm{P}, \mathrm{K}, \mathrm{S}$ and $\mathrm{B}$ fertilizers were broadcast just before sowing, and the rest of the $\mathrm{N}$ was top dressed after the first irrigation at crown root initiation (CRI) stage. Weeds were well-controlled by one hand weeding at 25-30 days after sowing (DAS), and there was no significant damage by insect and pests. The crop received three post-sowing irrigations at CRI (17-21 DAS), heading (55-60 DAS) and grain filling (75-80 DAS) stages.

\subsection{Artificial inoculation of MOT}

The trials were surrounded by border rows with mixture of varieties susceptible to leaf rust and leaf blight. The plants of border rows were inoculated by MoT spores for infection once in a week starting from three weeks after sowing until primary infection was observed. The crop was harvested at full maturity in each season. The inoculum were supplied by plant pathology laboratory of Regional Agricultural Research Station Jashore.

\subsection{Data collection}

Plant counting was made for number of plants in $1 \mathrm{~m}$ from each of 5 middle rows in case of yield trials $\left(\right.$ plants $/ \mathrm{m}^{2}$ ). Heading days was counted from sowing to the day when base of the $50 \%$ of the spikes just come out from the flag leaf sheath. Maturity days (physiological maturity) 
was determined visually and defined as the time when the $80 \%$ of the grains in the wheat spikes had turned yellowish.

Grain yield was determined by fresh harvesting of $3.2 \mathrm{~m}^{2}$ area $(4 \mathrm{~m} \times 0.8 \mathrm{~m})$. Fresh grain yield was converted to grain yield $\left(\mathrm{kg} \mathrm{ha}^{-1}\right)$ at $12 \%$ moisture content using the following formula:

$$
\text { Yadj }=Y_{\mathrm{AC}} \times \frac{\left(100-\mathrm{M}_{\mathrm{AC}}\right)}{\left(100-\mathrm{M}_{\mathrm{ST}}\right)}
$$

Where,

Yadj $=$ Adjusted yield, $\mathrm{Y}_{\mathrm{AC}}=$ Yield at actual moisture percent, $\mathrm{M}_{\mathrm{AC}}=$ Actual moisture percent,$\quad \mathrm{M}_{\mathrm{ST}}=$ Standard moisture percent

Grains spike $^{-1}$ was determined from ten randomly selected spikes, threshed all 10 spikes and counts all the grains of those spikes and divides by ten. Thousand grain weights (dry) were determined by oven drying @ $70{ }^{\circ} \mathrm{C}$ for $2-3$ days. Severity of wheat blast disease has scored at grain filling (80 DAS) stage according to following formula;

$$
\begin{aligned}
\% \mathrm{DS}= & (\% \text { spike incidence } / 100) *(\% \text { disease } \\
& \text { area on spike } / 100) * 100
\end{aligned}
$$

Where, DS $=$ Disease severity

Temperature and rainfall data during the experimental period were collected from the Regional Agricultural Research Meteorological Station, Jashore.

\subsection{Statistical analysis}

Data were analyzed by ANOVA (using Crop Stat 7.2) to evaluate differences between treatments, and the means were compared using least significant difference (LSD) at the 5\% level of significance $(\mathrm{p}<0.05)$.

\section{Results and Discussion}

\subsection{Effect of season (year) on crop growth and blast infestation}

\subsubsection{Effect on heading}

The highest mean heading day was 63 in 201718 and the lowest one was $61 \mathrm{~d}$ in 2016-17. The maturity (physiological maturity) days was highest (103d) in 2016-17, followed by 101d in 2017-18 and the lowest one was $98 \mathrm{~d}$ in 2015-16 (Table 1). Thus heading and maturity days were 1-2 days and 3-5 days shorten 2015-16 compared to that of 2016-16 and 2017-18. It might be due to the increase of temperature from first week of February (grain filling stage) to end of March which resulted earlier maturity.

The reduction of duration for wheat maturity with increasing temperature as reported by Fischer, 1985; Hakim et al., 2012; Hossain et al., 2012.

3.1.2 Effect on plant density (no. $\mathrm{m}^{-2}$ ) The highest mean plant density (no. $\mathrm{m}^{-2}$ ) was in 2016-17 (88 no. $\left.\mathrm{m}^{-2}\right)$ followed by $2017-18$ and the lowest one $\left(56\right.$ no. $\left.^{-2}\right)$ was in 2015-16 (Table 2 ). The variation in plant density might be due to variation of germination $(\%)$ or other unrecorded causes.

\subsubsection{Effect on yield and yield attributes of wheat}

Seasonal variation affected yield and yield attributes significantly in wheat (Table 2). The highest yield (3505 $\left.\mathrm{kg} \mathrm{ha}^{-1}\right)$ was observed in 2016-17 similar to 2017-18 (3448 kg ha $\left.{ }^{-1}\right)$ and the lowest one (1680 kg ha-1) was in 2015-16. Yield losses up to $100 \%$ are reported for susceptible cultivars (Goulart and Paiva, 2000).

The spike density (grain spike ${ }^{-1}$ ) was the highest (45) in 2016-17, followed by 44 in 2017-18 and the lowest one (43) was in 2015-16 (Table 2). Lower spike density in 2015-16 might be due to higher blast infestation.

The highest 1000 grain weight (36.6 g) was significantly higher in 2016-17, and the lowest (31.8 g) was in 2015-16 (Table 2), similar to 2017-18 (32.1 g). The reason was due to the heavy infection of blast both in optimum and late sowing condition, the severity and intensity were more devastating in late season sowing crop (\% blast index 33), which resulted small, shriveled and less seed weight (Goulart et al., 2007). 
Table 1. Effect of sowing time on the time from sowing to heading, physiological maturity and $\%$ blast disease index of old and newly released wheat varieties

\begin{tabular}{|c|c|c|c|}
\hline Variation source & Heading days (no.) & Maturity days (no.) & $\%$ blast disease index \\
\hline \multicolumn{4}{|l|}{ Year $(Y)$} \\
\hline $2015-16$ & 62 & 98 & 33.0 \\
\hline 2016-17 & 61 & 103 & 18.1 \\
\hline $2017-18$ & 63 & 101 & 12.1 \\
\hline \multicolumn{4}{|l|}{ Sowing time $(\mathrm{T})$} \\
\hline Optimum & 62 & 107 & 1.4 \\
\hline Late & 61 & 93 & 40.7 \\
\hline \multicolumn{4}{|l|}{ Variety $(\mathrm{V})$} \\
\hline Sonalika & 59 & 99 & 23.5 \\
\hline Kanchan & 65 & 101 & 22.0 \\
\hline Sourav & 65 & 102 & 2.3 \\
\hline Gourab & 59 & 101 & 9.9 \\
\hline Shatabdi & 67 & 104 & 6.8 \\
\hline Sufi & 59 & 100 & 17.0 \\
\hline Bijoy & 64 & 102 & 18.7 \\
\hline Prodip & 63 & 101 & 20.7 \\
\hline BARI Gom 25 & 62 & 102 & 35.3 \\
\hline BARI Gom 26 & 61 & 99 & 36.5 \\
\hline BARI Gom 27 & 65 & 100 & 28.7 \\
\hline BARI Gom 28 & 59 & 100 & 22.5 \\
\hline BARI Gom 29 & 59 & 100 & 30.7 \\
\hline BARI Gom 30 & 58 & 98 & 20.2 \\
\hline \multicolumn{4}{|l|}{$\mathrm{LSD}_{0.05}$} \\
\hline $\mathrm{Y}$ & 1.0 & 0.8 & 7.1 \\
\hline $\mathrm{T}$ & 0.8 & 0.7 & 5.8 \\
\hline V & 2.2 & 1.8 & 15.2 \\
\hline $\mathrm{Y} \times \mathrm{T}$ & ns & 1.2 & 9.9 \\
\hline $\mathrm{T} \times \mathrm{V}$ & 3.1 & 2.6 & 21.5 \\
\hline $\mathrm{Y} \times \mathrm{V}$ & ns & ns & ns \\
\hline $\mathrm{Y} \times \mathrm{T} \times \mathrm{V}$ & ns & ns & ns \\
\hline
\end{tabular}

$\mathrm{Y}=$ Year, $\mathrm{V}=$ Variety, $\mathrm{T}=$ Sowing time

\subsubsection{Effect on severity of wheat blast (\% blast} index)

The significantly higher disease severity was $33 \%$ in $2015-16$ followed by $18.1 \%$ in $2016-17$ and the lowest one was $12.1 \%$ in $2017-18$ (Table 1). Epidemic years are characterized by several days of continuous rains and average temperatures of $25-30{ }^{\circ} \mathrm{C}$ with spike wetness between 25 and $40 \mathrm{hrs}$ during the flowering stage of the crop (Cardoso et al., 2008). However, temperature was comparatively higher during grain formation period (temperature raised 1-3 ${ }^{\circ} \mathrm{C}$ started from $2^{\text {nd }}$ week of February and continued up to March) and also $15 \mathrm{~mm}$ rainfall at second week of February 2016, which played a crucial role on more disease severity $(33 \%)$ in 2015-16 (Fig. 1). Kohli et al. (2011) reported that wheat blast occurred from $18-25{ }^{\circ} \mathrm{C}$ during flowering, followed by hot and humid conditions. On the other hand, Cardoso et al. (2008) indicated that minimum temperature for disease infection is $10^{\circ} \mathrm{C}$ and the maximum is 32 
${ }^{\circ} \mathrm{C}$, with optimum between $25-30{ }^{\circ} \mathrm{C}$, was similar to our study.

\subsection{Effect of sowing time on the performance of} wheat

3.2.1 Effect of sowing time on crop development

There is a significant effect of sowing time between optimum and late sowing condition on crop development of wheat. The highest mean heading time (62 days) and maturity time (107 days) were observed in optimum sowing and the lowest heading (61 days) and maturity (93 days) in late sowing (Table 1). In case of optimum sowing (15-30 November), heading usually occurred at mid-January (average temperature 24 ${ }^{\circ} \mathrm{C}$ ), favourable for anthesis and resulted delay maturity. On the contrary, in late sowing (20-30 December), heading occurred after mid-February with higher temperature $\left(27^{\circ} \mathrm{C}\right)$ enhanced forced maturity and required less days (about 2 weeks) for attaining the maturity. It was observed that all cultivars sown in early need higher days compared to late sown (Hossain et al., 2012).

\subsubsection{Effect of sowing time on plant density} (no. $\mathrm{m}^{-2}$ )

The highest plants density (no. $\mathrm{m}^{-2}$ ) was observed in optimum sowing (74 plants $\mathrm{m}^{-2}$ )and lowest in late sowing (70 plants $\mathrm{m}^{-2}$ ) (Table 2). The reason might be low temperature (about 2 ${ }^{\circ} \mathrm{C}$ ) at the sowing time in late sowing than that of optimum sowing time.

\subsubsection{Effect sowing time on yield and yield attributes of wheat}

Sowing time had significant effect on yield and yield attributes of wheat. The significantly higher yield (4060 $\mathrm{kg} \mathrm{ha}^{-1}$ ) was recorded in optimum sowing time and the lowest yield (1695 $\mathrm{kg} \mathrm{ha}^{-1}$ ) was in late sowing (Table 2). In optimum sowing environment were favourable for good grain formation but in late sowing temperature became higher up to $37.6{ }^{\circ} \mathrm{C}$ resulted forced maturity. Furthermore, in late sowing plants, the severity and intensity of wheat blast was more (\% blast index $40.7 \%$ ), resulted less grain weight and grains spike ${ }^{-1}$ which contributed a significant yield loss. Highest yield losses occur when spike infections begin during flowering or early grain formation (Goulart et al., 2007).

The mean grain spike ${ }^{-1}$ was significantly higher in optimum sowing time (44) and the lowest (40) in late sowing condition (Table 2). The grain spike $^{-1}$ was higher $(17 \%)$ in optimum sowing condition than in late seeding condition. This may be due to the higher temperature $\left(2{ }^{\circ} \mathrm{C}\right)$ at grain filling stage in optimum sowing than late sowing, caused sterility and produced lower grains. The 1000 grain weight (43.6 g) was higher in optimum sowing time and the lower(23.3g) in late sowing (Table 2).

\subsubsection{Effect on disease severity (\% blast index)} The higher disease infestation occurred (mean $\%$ blast disease index $40.7 \%$ ) was in late sowing whereas, it was very minimum (mean \% blast disease index $1.4 \%$ ) in optimum sowing condition (Table1). In late condition, the severity and intensity were forty times more devastating than that of optimum sowing condition. Our observations was higher temperature, with some rainfall (15 $\mathrm{mm}$ in $2015-16,0.2 \mathrm{~mm}$ in $2016-17$ and $0.2 \mathrm{~mm}$ in 2017-18), accelerates the severity and intensity of wheat blast at grain formation period in each of the years similar to that of Urashima et al. (2009).

\subsection{Effect of variety on the performance of wheat \\ 3.3.1 Effect of cultivar/variety on crop development}

Among varieties there was significant variation on heading duration and maturity days of wheat. The higher heading period was required in the variety Shatabdi (67 d), similar to Kanchan, Saurav, and BARI Gom 27 at $65 \mathrm{~d}$ and the lower in the BARI Gom 30 (58 d) (Table 1). Similarly, the higher days were recorded in Shatabdi (104 d), followed by $102 \mathrm{~d}$ in Kanchan, Bijoy and BARI Gom 25 and the lower in BARI Gom 30 (98 d). The difference in crop development (both in heading and maturity) among the wheat varieties may be due the varietal character (crop 
duration/life duration). Days to physiological maturity of wheat cultivars also showed a significant variation due to inherent differences between the cultivars (Shahzad et al., 2007). Up to 29 November Gourab need minimum and after 29 November Sufi need minimum days to get physiological maturity. Spink et al. (1993) also observed that delayed sowing shortens the duration of each development phase due to rising of temperature.

\subsubsection{Effect of cultivar/variety time on plant density (no. $\mathrm{m}^{-2}$ )}

Plant density (no. $\mathrm{m}^{-2}$ ) was also significantly influenced by the variety. The significant highest plant density (no. $\mathrm{m}^{-2}$ ) was observed in Sonalika (80 no. $\mathrm{m}^{-2}$ ), similar to Kanchan (79), Sourav (74) and BARI Gom 28 (76) and the lowest (62) in the variety Prodip (Table 2).

Table 2. Yield and yield attributes of wheat under optimum and late sowing conditions

\begin{tabular}{|c|c|c|c|c|}
\hline Variation source & $\begin{array}{l}\text { Plants density } \\
\left(\text { no. } \mathrm{m}^{-2}\right)\end{array}$ & Grains spike $^{-1}$ & $\begin{array}{l}1000 \text { grain } \\
\text { weight }(\mathrm{g})\end{array}$ & $\begin{array}{l}\text { Grain yield } \\
\left(\mathrm{kg} \mathrm{ha}^{-1}\right)\end{array}$ \\
\hline \multicolumn{5}{|l|}{ Year (Y) } \\
\hline $2015-16$ & 56 & 43 & 31.8 & 1680 \\
\hline $2016-17$ & 88 & 45 & 36.6 & 3505 \\
\hline $2017-18$ & 72 & 44 & 32.1 & 3448 \\
\hline \multicolumn{5}{|l|}{ Sowing time $(\mathrm{T})$} \\
\hline Optimum & 74 & 48 & 43.6 & 4060 \\
\hline Late & 70 & 41 & 23.4 & 1696 \\
\hline \multicolumn{5}{|l|}{ Variety (V) } \\
\hline Sonalika & 80 & 39 & 31.2 & 2584 \\
\hline Kanchan & 79 & 42 & 32.3 & 2479 \\
\hline Sourav & 74 & 52 & 26.2 & 2963 \\
\hline Gourab & 77 & 40 & 37.5 & 3395 \\
\hline Shatabdi & 72 & 46 & 34.0 & 3160 \\
\hline Sufi & 69 & 51 & 31.8 & 3193 \\
\hline Bijoy & 75 & 41 & 34.7 & 2869 \\
\hline Prodip & 62 & 48 & 41.0 & 3096 \\
\hline BARI Gom 25 & 65 & 40 & 37.8 & 2621 \\
\hline BARI Gom 26 & 67 & 47 & 31.3 & 2464 \\
\hline BARI Gom 27 & 69 & 45 & 28.3 & 2339 \\
\hline BARI Gom 28 & 76 & 44 & 35.0 & 3196 \\
\hline BARI Gom 29 & 73 & 42 & 34.5 & 2798 \\
\hline BARI Gom 30 & 73 & 41 & 33.0 & 3134 \\
\hline \multicolumn{5}{|l|}{$\mathrm{LSD}_{0.05}$} \\
\hline $\mathrm{Y}$ & 2.9 & 1.2 & 1.7 & 153.9 \\
\hline $\mathrm{T}$ & 2.4 & 0.9 & 1.4 & 125.7 \\
\hline V & 6.3 & 2.5 & 3.6 & 332.5 \\
\hline $\mathrm{Y} \times \mathrm{T}$ & 4.1 & 1.6 & 2.4 & 217.7 \\
\hline $\mathrm{T} \times \mathrm{V}$ & 8.8 & 3.5 & 5.1 & 470.3 \\
\hline $\mathrm{Y} \times \mathrm{V}$ & $\mathrm{ns}$ & ns & ns & ns \\
\hline $\mathrm{Y} \times \mathrm{T} \times \mathrm{V}$ & ns & ns & ns & ns \\
\hline
\end{tabular}

$\mathrm{Y}=$ Year, $\mathrm{V}=$ Variety, $\mathrm{T}=$ Sowing time 


\subsubsection{Effect cultivars/varieties on yield and yield attributes of wheat}

There were significant effect on yield and yield attributes of wheat due to the effect of different crop varieties both in optimum and later sowing condition (Table 2). The highest grain yield ( $\mathrm{kg}$ $\mathrm{ha}^{-1}$ ) was observed in the wheat variety Gourab (3395 $\left.\mathrm{kg} \mathrm{ha}^{-1}\right)$, similar to BARI Gom 28 (3196 $\left.\mathrm{kg} \mathrm{ha}^{-1}\right)$, Sufi $\left(3193 \mathrm{~kg} \mathrm{ha}^{-1}\right)$, Shatabdi $(3160 \mathrm{~kg}$ $\left.\mathrm{ha}^{-1}\right)$ and BARI Gom $30\left(3134 \mathrm{~kg} \mathrm{ha}^{-1}\right)$ and lowest in Kanchan $\left(2479 \mathrm{~kg} \mathrm{ha}^{-1}\right)$ and Sonalika $\left(2584 \mathrm{~kg} \mathrm{ha}^{-1}\right)$, the old varieties, similar to the newly released wheat varieties like BARI Gom $26\left(2464 \mathrm{~kg} \mathrm{ha}^{-1}\right)$ and BARI Gom $27(2339 \mathrm{~kg}$ $\left.\mathrm{ha}^{-1}\right)$. The reason of good crop yield due to the more grain weight (34-37.5 gm in the old varieties and 33-35 gm in the new varieties) as well as less blast infection (\%index 6.8-9.9 in the old verities and $20.2-22.5 \%$ in the newly released varieties). The highest grain spike ${ }^{-1}$ was observed in Sourav (52 gains spike ${ }^{-1}$ ), similar to Sufi (51 gains spike ${ }^{-1}$ ) and lowest in Sonalika (39 gains spike ${ }^{-1}$ ) showed in Table 2. The intensity and severity of wheat blast were not affecting on grain spike ${ }^{-1}$ at last three consecutive years.

The highest 1000 grain weight recorded in the variety Prodip (41 g), similar to BARI Gom 25 $(37.7 \mathrm{~g})$ and lowest in Sourav (26.2 g).Grains from blast-infected spikes from highly susceptible cultivars are often small, shrivelled and deformed, with low test weight (Goulart $e t$ al.,2007).

\subsubsection{Effect cultivars/varieties on disease severity of wheat blast (\% blast index)}

There were wide ranges (2.3-36.5\%) of wheat blast disease infestation among the varieties with significant differences (Table 1). The highest disease infestation was recorded in BARI Gom $26(36.5 \%)$, similar to BARI Gom 25, 27 and 29 (28.7-35.3\%) and lowest in Sourav (2.3\%), similar to Shatabdi $(6.8 \%)$ and Gourab (9.9\%). The newer varieties were more susceptible to wheat blast disease (\% blast disease index 20-2$36.5 \%$ ) compared to the older varieties (\% blast disease index 2.3-23.5\%).

\section{Conclusions}

From the above results it may be concluded that virulent inoculums, higher temperature (30-32 $\left.{ }^{\circ} \mathrm{C}\right)$ and some rainfall $(10-20 \mathrm{~mm})$ especially in heading stage (58-67 d in different varieties) played a key role for wheat blast disease development. However, the variety BARI Gom 28 and 30 (newly released) and Sourav, Gourab and Shatabdi (old variety) were found some tolerant capacity against wheat blast disease maintaining a good yield of over $3 \mathrm{t} \mathrm{ha}^{-1}$. In addition, timely or early sowing (15-30 November) of wheat is very much crucial to avoid what blast disease infection. This is due to less chance of rainfall occur in heading to flowering stage. Research should be done to find out the proper resistant line against wheat blast disease screening through artificial inoculations, and proper control measures should be suggested against controlling of wheat blast disease in collaboration with local and international research organizations.

\section{References}

Alam, M. J., Humphreys, E., Sarkar, M. A. R. and Sudhir-Yadav. 2018. Intensification and diversification increase land and water productivity and profitability of rice-based cropping systems on the High Ganges River Floodplain of Bangladesh. Field Crops Research, 209: 10-26.

Alam, M. J., Humphreys, E., Sarkar, M. A. R. and Sudhir-Yadav. 2017. Comparison of dry seeded and puddle transplanted rainy season rice on the High Ganges River Floodplain of Bangladesh. European Journal of Agronomy, 96: 120-130.

Callaway, E. 2016. Devastating wheat fungus appears in Asia for the first time. Nature, 532: 421-422.

Cardoso, C. D. A., Reis, E. M. and Moreira, E. N. 2008. Development of a warning system for wheat blast caused by Pyricularia grisea. Summa Phytopathologica, 34: 216-221. 
Castroagudín, V. L., Moreira, S. I., Pereira, D. A., Moreira, S. S., Brunner, P. C., Macie, J. L., Crous, P. W., McDonald, B. A., Alves, E. and Ceresini, P. C. 2016. Pyricularia graminis-tritici, a new Pyricularia species causing wheat. Persoonia, 37: 199-216.

Duveiller, E., He, X.and Singh, P. K. 2016. Wheat Blast: An Emerging Disease in South America Potentially Threatening Wheat Production. In: World Wheat Book: A History of Wheat, (ed.). A. Bonjean, M. van Ginkel, Lavoisier, Paris, France, 1107-1122 pp.

Farman, M., Peterson, G., Chen, L., Valent, B., Bachi, P., Murdock, L., Hershman, D., Pedley, K., Fernandes, M.and Bavaresco, J. 2017. The Lolium pathotype of Magnaporthe oryzae recovered from a single blasted wheat plant in the United States. Plant Disease, 101: 684-692.

Fischer, R. A. 1985. Number of kernels in wheat crops and the influence of solar- radiation and temperature. Journal of Agricultural Science, 105: 447-461.

Goulart, A. C. P. and Paiva, F. A. 1992. Incidência da brusone (Pyricularia oryzae) em diferentes cultivares de trigo (Triticum aestivum) em condições de campo. Fitopatologia Brasileira, 17: 321325.

Goulart, A. C. P.and Paiva, F. A. 2000. Perdas no rendimento de grãos de trigo causada por Pyricularia grisea, nos anos de 1991e 1992, no Mato Grosso do Sul. Summa Phytopathol, 26: 279-282.

Goulart, A. C. P., Sousa, P. G. and Urashima, A.S. 2007. Damages in wheat caused by infection of Pyricularia grisea. Summa Phytopathol, 33: 358-363.

Hakim, M. A., Hossain, A., Teixeira da Silva, J. A., Zvolinsky, V. P. and Khan, M. M. 2012. Yield, protein and starch content of 20 wheat (Triticum aestivum L.) genotypes exposed to high temperature under late sowing conditions. Journal of Scientific Research, 4(2): 477-489.

Hossain, A., Teixeira da Silva, J. A., Lozovskaya, M. V. and Zvolinsky, V. P. 2012. The effect of high temperature stress on the phenology, growth and yield of five wheat (Triticum aestivum L.) genotypes. The Asian and Australasian Journal of Plant Science and Biotechnology, 6(1): 14-23.

Igarashi, S., Utimada, C., Igarashi, L., Kazuma, A. and Lopes, R. 1986. Pyricularia sp. emtrigo. I. Ocorrência de Pyricularia sp. no Estado do Paranà. Fitopatologia Brasileira, 11: 351-352.

Islam, M. T., Croll, D., Gladieux, P., Soanes, D. M., Persoons, A., Bhattacharjee, P., Hossain, M.S., Gupta, D. R., Rahman, M. M., Mahboob, M. G., Cook, N., Salam, M. U., Surovy, M.Z., Sancho, V. B., Maciel, J. L. N., NhaniJúnior, A., Castroagudín, V. L., Reges, J. T. A., Ceresini, P. C., Ravel, S., Kellner, R., Fournier, E., Tharreau, D., Lebrun, M. H., McDonald, B. A., Stitt, T., Swan, D., Talbot, N. J., Saunders, D. G. O., Win, J. and Islam, S. K. 2016. Emergence of wheat blast in Bangladesh was caused by a South American lineage of Magnaporthe oryzae. BMC Biology, 14: 84.

Kohli, M. M., Mehta, Y. R., Guzman, E., De Viedma, L.and Cubilla, L. E., 2011. Pyricularia blast -a threat to wheat cultivation. Czech Journal of Genetics and Plant Breeding 47: 130-134.

Maciel, J. L.N., Danelli, A. L.D., Boaretto, C. and Forcelini, C.A. 2013. Diagrammatic scale for the assessment of blast on wheat spikes. Summa Phytopathologica, 39: 162-166.

Malaker, P. K., Barma, N. C. D., Tiwari, T. P., Collis, W. J., Duveiller, E., Singh, P. K., Joshi, A. K., Singh, R. P., Braun, H. J., Peterson, G. L., Pedley, K. F., Farman, M. 
L. and Valent, B. 2016. First report of wheat blast caused by Magnaporthe oryzae pathotype triticum in Bangladesh. Plant Disease, 100: 2330-2330.

Ribot, C., Hirsch, J., Balzergue, S., Tharreau, D., Notteghem, J.H., Lebrun, M.H. and Morel, J.B. 2008. Susceptibility of rice to the blast fungus, Magnoporthe grisea. Journal of Plant Physiology, 165: 114124.

Shahzad, M. A., Wasi -ud - Din, Sahi, S. T., Khan, M. M., Ehsanullah, andAhmad, M. 2007. Effect of sowing dates and seed treatment on grain yield and quality of wheat. Pakistan Journal of Agricultural Science, 44: 581-583.

Silva, W. L., Cruz, M. F. A., Fortunato, A. A. and Rodrigues, F. A. 2015. Histochemical aspects of wheat resistance to leaf blast mediated by silicon. Scientia Agricola, 72: 322-327.
Spink, J. H., Clare, R. W. and Kilpatricks, J. B. 1993. Grain quality of milling wheat at different sowing dates. Applied Biology, 36: 231- 240 .

Urashima, A. S., Grosso, C., Stabili, A., Freitas, E., Silva, D., Netto, D., Franco, I. and Bottan, M. 2009. Effect of Magnaporthe grisea on seed germination, yield and quality of wheat. In: Advances in genetic, Genomics and Control of Rice Blast Disease, (ed.). G. L. Wang, B. Valent, Springer, Netherlands, 267-277pp.

Urashima, A. S., Hashimoto, Y., Don, Y., Kusaba, M., Tosa, Y., Nakayashiki, H. and Mayama, S. 1999. Molecular analysis of the wheat blast population in Brazil with a homolog of retrotransposon MGR583. Annals of the Phytopathological Society of Japan, 65: 429-436. 